7. Reprod. Fert. (1971) 27, 273-275

\title{
SEX CHROMATIN IN THE AMNION OF THE PIG
}

\author{
M. J. A. HARVEY \\ Department of Veterinary Reproduction, \\ University of Glasgow Veterinary Hospital, \\ Bearsden Road, Bearsden, Glasgow
}

(Received 24th May 1971)

In the domestic pig, Sus scrofa, sexual dimorphism, as indicated by the presence of the sex chromatin body, is detectable in neurones of the brain and spinal cord (Cantwell, Johnston \& Zeller, 1958; Hay \& Moore, 1961; Harvey, 1969). Attempts to detect this feature in non-nervous tissue have, with one exception, failed. Hoshino \& Toryu (1958) claimed to be able to demonstrate sexual dimorphism in eleven such tissues but these findings have not been substantiated (Hay \& Moore, 1961; Harvey, 1969).

During a study on sex chromatin in various tissues including nervous tissue, liver and skin (Harvey, 1969), it was decided to examine foetal tissues including amnion. It was considered that this latter tissue might be suitable for demonstrating sex chromatin, such a feature having been demonstrated in man (Klinger, 1957) and in two domestic species, cattle (Møller \& NeimannSørensen, 1957) and sheep (Bruere, 1968). In these three species, a wide variation in frequency of the sex-chromatin body was found, ranging from 85 to $97 \%$ in man to 58 to $68 \%$ in cattle and 24 to $61 \%$ in sheep. In males, the frequency of sex-chromatin-positive cells has been found to be very low in man and sheep but, in cattle, up to $14 \%$ of cells have been found to contain the body. Because of these findings, amniotic membranes in the pig were studied to determine if non-nervous tissues demonstrated sexual dimorphism, to compare the frequency found with that of other species and also the feasibility of studying the sex chromatin content of pig foetuses in experimental work.

Pregnant uteri were collected at the Glasgow Slaughter House at various stages of gestation ranging from 30 to 95 days, the age being calculated from the crown-rump length using the formula of Marrable \& Ashdown (1967). An incision through the wall of the uterus was made over the foetus situated at the apex of one horn. The membranes were dissected out to expose the amnion. Using a scalpel blade, a stab incision was made through the membrane, the incision being wide enough to permit the entrance into the amniotic sac of a 1 -in.-wide alcohol-cleaned microscope slide. The slide was pushed under the amnion until approximately three-quarters of the length was covered by membrane. A sufficient area of membrane was then cut off to allow for part of the amnion to be reflected onto the underside of the slide, thus ensuring firmer attachment to the glass. Care was taken to remove any air bubbles trapped under the amnion before fixing in Papanicolau's fixative for $24 \mathrm{hr}$. This process of dissection was repeated for each foetus. Staining was carried out using 
$2 \%$ cresyl violet and the method of Moore \& Barr (1953) before permanent mounting using D.P.X. (G. T. Gurr, Ltd).

Of the fifty-four foetuses studied, eight at the 30-day stage were sexed by histological examination of the gonads, the external genitalia at this stage being undifferentiated. Older foetuses varying in age from 42 to 95 days were either sexed by the appearance of the external genitalia alone (thirty-four foetuses) or by the use of both the above methods (twelve foetuses). The slides bearing the amnion were re-coded before analysis to ensure that the examiners did not know the identity, and therefore the sex, at the time of the study.

Examination of the amnion revealed the presence of five distinct layers of cells, the middle one of which revealed the presence of a small darkly staining body flattened against the periphery of the nuclei of female cells, but not of male cells. In each preparation, 100 cells were examined at a magnification of $\times 1250$, the number of sex chromatin positive cells was noted and from this, the genotypic sex of each foetus was determined (Plate 1).

TABLE 1

FREQUENGY OF SEX CHROMATIN BODIES IN AMNION PREPARATIONS OF THE PIG

\begin{tabular}{l|c|c|c|c|c}
\hline $\begin{array}{c}\text { Sex of } \\
\text { foetus }\end{array}$ & $\begin{array}{c}\text { No. of } \\
\text { foetuses }\end{array}$ & $\begin{array}{c}\text { Age range } \\
\text { (days) }\end{array}$ & $\begin{array}{c}\text { Range of } \\
\text { incidence } \\
\text { of sex } \\
\text { chromatin }\end{array}$ & $\begin{array}{c}\text { Mean \% } \% \\
\pm S . D .\end{array}$ & $\begin{array}{c}\text { Accuracy of } \\
\text { sexing by } \\
\text { sex chromatin }\end{array}$ \\
\hline $\begin{array}{c}\text { Male } \\
\text { Female }\end{array}$ & 30 & $\begin{array}{c}30 \text { to } 95 \\
0\end{array}$ & $\begin{array}{c}0 \text { to } 3 \\
25 \text { to } 62\end{array}$ & $\begin{array}{c}0 \cdot 4 \pm 1 \cdot 6 \\
42 \cdot 87 \pm 9.5\end{array}$ & $\begin{array}{l}100 \% \\
100 \%\end{array}$ \\
\hline
\end{tabular}

After this procedure was carried out, the identity of the foetus was revealed and its phenotypic sex compared with the genotypic sex. The results of the study are presented in Table 1. In all the fifty-four foetuses studied, the sexchromatin incidence accorded with the phenotypic sex. From this, it is clear that the amnion examination is an accurate method for determining the genotypic sex of pig foetuses, there being no overlap of incidence between females and males $(42 \cdot 87 \% \pm 9.5$ and $0.4 \% \pm 1 \cdot 6$, respectively). These frequencies are similar to those found in the sheep (Bruere, 1968) but lower than in the other species studied. Whether this is a species difference or due to variations in the criteria used in identification of the body must await further studies.

This study has revealed that, in pig foetuses from as early as 30 days, tissues other than neurones show sexual dimorphism. This technique may be a useful research tool in studies of prenatal pigs where the genotypic sex must be known quickly and without damage to the foetuses.

The author wishes to acknowledge the financial assistance of the Meat and Livestock Commission.

\section{REFERENCES}

Bruere, A. N. (1968) The demonstration of a sex chromatin body in amniotic tissue of the sheep. Can. 7. Genet. Cytol. 8, 502. 


\section{PLATE 1}

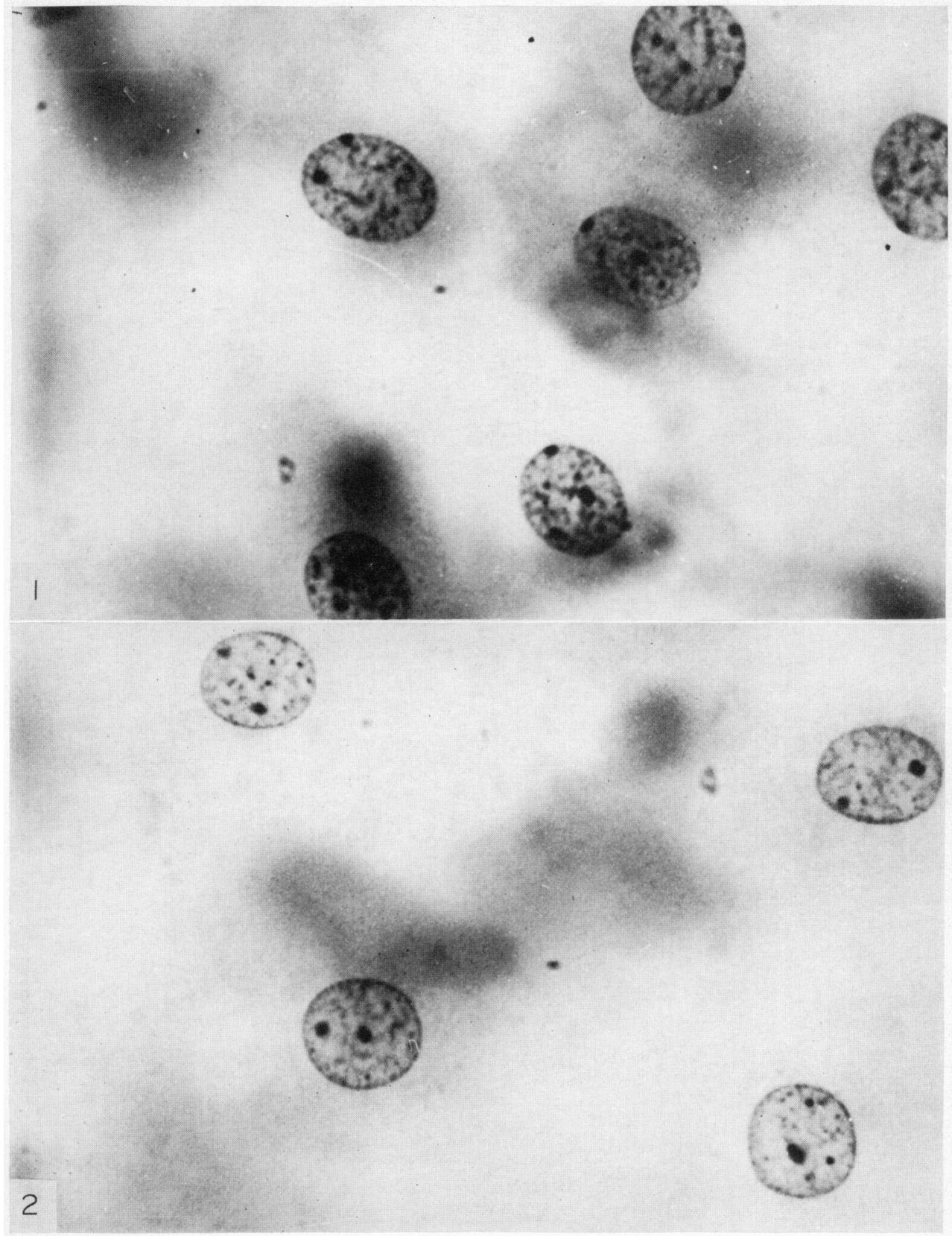

Fig. 1. Sex chromatin-negative cells from amnion of female foetus. $\times 2000$.

Fig. 2. Sex chromatin-negative cells from amnion of male foetus. $\times 2000$. 
Gantwell, G. E., Johnston, E. F. \& Zeller, J. H. (1958) The sex chromatin of swine intersexes. 7. Hered. 49, 180.

HaRveX, M. J. A. (1969) A study of cytogenetics in the pig. Ph.D. thesis, University of Glasgow Library.

HAY, J. C. \& MOORE, K. L. (1961) The sex chromatin in various mammals. Acta anat. 45, 289.

Hoshino, T. \& Toryu, Y. (1958) Sex chromatin in domestic animals. F. agric. Res. 9, 113.

KLINGER, H. P. (1957) The sex chromatin in fetal and maternal portions of human placenta. Acta anat. 30, 371 .

Marrable, A. W. \& Ashdown, R. R. (1967) Quantitative observations on pig embryos of known ages. 7. agric. Sci., Camb. 69, 443.

Møller, F. \& Nermann-Sørensen, A. (1957) Cytological sex determination in cattle on basis of chorionic cells. Nord. VetMed. 9, 675.

Moore, K. L. \& BARR, M. L. (1953) Morphology of the nerve cell nucleus in mammals, with special reference to the sex chromatin. J. comp. Neurol. 98, 213. 